\title{
Creatine Kinase
}

\section{MODIFICATION OF THE WORKING ENZYME}

\author{
By E. JAMES MILNER-WHITE and IAIN D. KELLY \\ Department of Biochemistry, University of Glasgow, Glasgow G12 8QQ, Scotland, U.K.
}

(Received 26 September 1975)

\begin{abstract}
Protection against inhibition of creatine kinase by iodoacetamide is measured by the decrease in the rate constant for the inhibition reaction. A mixture of purified substrates at equilibrium protects quite strongly when all the components of the mixture are nearly saturating. The protection by substrates 'working' in the forward direction only (from creatine and MgATP) was measured by carrying out the experiment rapidly at low concentrations of the enzyme; by varying the concentration of substrateit was found that the amount of protection when the substrates of the forward reaction are saturating is about $80 \%(100 \%$ protection would imply a value of zero for the rate constant of the inhibition reaction). The effects of $\mathrm{Ca}^{2+}$ and $\mathbf{M g}^{2+}$ are compared. It is already known that the complex creatine- $\mathrm{NO}_{3}{ }^{-}-\mathrm{MgADP}$, which is considered to be either a transition-state analogue or an analogue of an intermediate in the reaction pathway, protects fully against iodoacetamide, whereas creatine and $\mathrm{MgADP}$ alone, or together without $\mathrm{NO}_{3}{ }^{-}$, do not protect. This suggests that the degree of protection by the working enzyme represents the proportion of enzyme molecules that have a conformation complementary to a creatine- $\mathrm{PO}_{3}-\mathrm{MgADP}$ intermediate.
\end{abstract}

Rabbit skeletal-muscle creatine kinase has a single fast reacting cysteine residue per active site. Watts et al. (1961) showed, using an iodide-sensitive electrode to estimate the extent of the chemical reaction, that the reaction with iodoacetate is proportional to the loss of enzymic activity. Complete reaction resulted in almost complete activity loss. In the present work incorporation of iodo $\left[{ }^{14} \mathrm{C}\right]$ acetamide into protein is used as a measure of the reaction.

Watts \& Rabin (1962) originally observed that there was protection by an equilibrium mixture of substrates, but not by individual substrates, against iodoacetamide inhibition. However, Morrison \& James (1965) demonstrated, using initial-velocity kinetics, that the dead-end complex creatine-MgADP bound to the enzyme quite strongly; O'Sullivan et al. (1966) then showed that the complex protected strongly against iodoacetamide inhibition. Since creatine and MgADP are both components of the substrate equilibrium mixture, the presence of the complex seemed to be giving rise to all the protection seen in the mixture. The picture was further altered when Milner-White \& Watts $(1970,1971)$ found that the combination of creatine and MgADP did not after all protect and that protection was only seen when small anions such as chloride, formate or nitrate were added. Such anions had always been present in previous experiments.

The specificity for the anion suggested that the anion was binding to the enzyme in the position between the creatine and the ADP; further, the binding of these substrates as components of the complex was stronger than their normal binding, so Milner-White \& Watts (1971) proposed that the complex was a transition-state analogue or at least an analogue of an intermediate state of the reaction. Reed \& Cohn (1972) studied the e.p.r. (electronparamagnetic-resonance) spectra of the paramagnetic $\mathrm{Mn}^{2+}$ ion substituting for $\mathrm{Mg}^{2+}$; they showed that in the anion complex almost all the water molecules were removed from the first co-ordination sphere of the $\mathrm{Mn}^{2+}$ ion, which as a result had a highly distorted electronic environment. Proton n.m.r. (nuclear-magnetic-resonance) studies using formate as the anion have shown that it is indeed situated on the enzyme in the expected position between the two substrates (Reed \& McLaughlin, 1974). James \& Cohn (1974) have used a double-resonance technique with the same complex to detect evidence for the presence of a lysine residue very near to the formate anion.

Brief re-investigation of a substrate equilibrium mixture without small anions added to it showed that a small degree of protection against iodoacetamide was still observed (Milner-White \& Watts, 1971); the e.p.r. spectra of the $\mathrm{Mn}^{2+}$ ion in such a mixture indicated some small changes towards asymmetry of the metal-ion environment, but not the characteristic 
fine-structure splitting found with the creatine$\mathrm{NO}_{3}{ }^{-}-\mathrm{MnADP}$ complex (Reed \& Cohn, 1972). In the present study the effect of the substrate equilibrium mixture has been more closely studied by using substrates purified to remove any small anions that might be present.

\section{Materials and Methods \\ Materials}

ATP and ADP were purchased from Boehringer Corp., Lewes, Sussex BN7 1LG, U.K. ADP and creatine phosphate were obtained from Sigma (London) Chemical Co., Kingston-upon-Thames, Surrey KT2 7BH, U.K. They were purified further as indicated. Creatine and Bicine [ $N N$-bis-(2-hydroxyethyl)glycine] (BDH Chemicals, Poole, Dorset BH12 4NN, U.K.) were recrystallized once from $1 \mathrm{~mm}$-EDTA, pH 9.0, and once from water. Iodoacetamide (BDH Chemicals) was recrystallized five times from aq. $50 \%$ (v/v) ethanol. Iodo $\left[1{ }^{14} \mathrm{C}\right]$ acetamide was purchased from The Radiochemical Centre, Amersham, Bucks. HP7 9LL, U.K.; its specific radioactivity was $33 \mathrm{mCi} / \mathrm{mol}$.

The substrates ATP, ADP and creatine phosphate, as their sodium salts, were all individually purified by passing them down a P2 Bio-Gel (Bio-Rad Laboratories, St. Albans, Herts., U.K.) column. No buffer was used, but the substrates were made up to $\mathrm{pH} 7.2$ with $\mathrm{NaOH}$ before addition to the column. The substrates are partially excluded from the interior of the gel, whereas $\mathrm{NO}_{3}{ }^{-}$ions (and presumably any other small ions that might interfere in this system; see Milner-White \& Watts, 1971) appear to penetrate all the available space in the gel and are eluted later. $V_{0}$ for Blue Dextran $=128 \mathrm{ml} ; V_{\mathrm{e}}$ for ATP $=145 \mathrm{ml}$; $V_{\mathrm{e}}$ for $\mathrm{ADP}=155 \mathrm{ml} ; V_{\mathrm{e}}$ for creatine phosphate $=$ $180 \mathrm{ml} ; V_{\mathrm{e}}$ for $\mathrm{NO}_{3}{ }^{-}$ions $=225 \mathrm{ml}$. Later, nonpurified substrates were used, since they behaved like the purified substrates.

The enzyme was prepared as described previously (Milner-White \& Watts, 1971). It was filtered through a Millipore filter (pore size $0.22 \mu \mathrm{m}$ ) and stored in $50 \%(\mathrm{v} / \mathrm{v})$ glycerol at $-20^{\circ} \mathrm{C}$. It was homogeneous by the criteria of polyacrylamide-gel electrophoresis in Tris (50 mm) adjusted with acetic acid to pH9.0, and by gel chromatography on a Sephadex G-150 column. The specific activity of the enzyme was $0.13-0.15 \mu \mathrm{mol}$ of product released $/ \mathrm{min}$ per $\mu \mathrm{g}$ of protein in the forward direction under the conditions used by Milner-White \& Watts (1971) at $30^{\circ} \mathrm{C}, \mathrm{pH} 9.0$.

\section{Inhibition by iodoacetamide: protection by non-working substrates and substrate equilibrium mixture}

The experiments were carried out in Bicine (20 mM) buffer made up with $\mathrm{CO}_{2}$-free $\mathrm{NaOH}$ to pH9.0. A portion $(0.1 \mathrm{ml})$ of the enzyme solution mixed with any added substrates was removed before addition of the iodoacetamide, diluted in cysteine $(10 \mathrm{~mm})$ buffer $(0.9 \mathrm{ml})$, previously adjusted to $\mathrm{pH} 9.2$ with $\mathrm{NaOH}$, and kept for assay at room temperature $\left(20^{\circ} \mathrm{C}\right)$. After addition of the inhibitor and mixing, further samples $(0.1 \mathrm{ml})$ were removed at timed intervals, usually 10 and $20 \mathrm{~min}$, and diluted in the cysteine buffer. After storage at room temperature, samples $(0.1 \mathrm{ml})$ of all the diluted enzyme solutions were assayed as described below. For experiments carried out at $0^{\circ} \mathrm{C}$ the cysteine concentration of the stopping buffer was $40 \mathrm{~mm}$; also all tubes were sealed.

\section{Enzyme assay}

This was as previously described (Milner-White \& Watts, 1971) with certain modifications. It was performed under a gentle stream of $\mathrm{N}_{2}$ gas. A difficulty often encountered with pH-stat assays is that it is awkward to adjust the $\mathrm{pH}$ of the solution in which the enzyme is diluted to exactly that of the poorly buffered reaction mixture; as a result either a lag or an initial over-addition of titrant is liable to occur. To overcome this, no attempt was made to adjust the pH of the enzyme solution to exactly that of the assay, but instead the addition of titrant was initiated, immediately after mixing enzyme and substrates, by altering the setting for the $\mathrm{pH}$ at which the reaction was to occur. Fortunately the initial rate of the forward reaction with high substrate concentrations and either $\mathrm{Mg}^{2+}$ or $\mathrm{Ca}^{2+}$ ions is almost independent of $\mathrm{pH}$ between the values 8.4 and 9.6. To facilitate the fine adjustment of the $\mathrm{pH}$-setting a slow-motion friction drive was fitted (Epicyclic friction drive, ratio $6: 1$ ).

Protein concentration was determined spectrophotometrically at $280 \mathrm{~nm}$ (Milner-White \& Watts, 1971), assuming a molecular extinction coefficient of $7.45 \times 10^{4}$.

Protection by 'forward-working' substrates against iodoacetamide inhibition

These experiments were carried out at $30^{\circ} \mathrm{C}$ in Bicine (10 mM) buffer adjusted to $\mathrm{pH} 9.0$ with $\mathrm{CO}_{2}$-free $\mathrm{NaOH}(8.2 \mathrm{~mm})$; they contained sodium acetate $(0.1 \mathrm{M})$ to maintain the ionic strength $(I 0.11) . \mathrm{Mg}^{2+}$ and $\mathrm{Ca}^{2+}$ were added as their acetate salts to a concentration of $1 \mathrm{~mm}$ above that of the ATP to ensure complete chelation of the nucleotide. The enzyme $(10 \mu \mathrm{l})$ was mixed quickly with $0.89 \mathrm{ml}$ of buffer solution containing substrates, where present, just before the addition of iodoacetamide $(0.1 \mathrm{ml})$, giving a volume of $1 \mathrm{ml}$. All concentrations mentioned are expressed as their values in this final volume. After exactly $1 \mathrm{~min}$ the iodoacetamide reaction was terminated by adding $10 \mu \mathrm{l}$ of cysteine $(1 \mathrm{M})$ adjusted to $\mathrm{pH} 9.4$ with $\mathrm{NaOH}$. After a further $1 \mathrm{~min}$ at $30^{\circ} \mathrm{C}$, a portion $(0.5 \mathrm{ml})$ was removed and assayed in a volume of $2 \mathrm{ml}$ by the pH-stat method described above, at $30^{\circ} \mathrm{C}$, at $\mathrm{pH} 9.1 \pm 0.2$. The assays contained near-saturating concentrations of substrates; creatine, 
40mM; ATP, $4 \mathrm{~mm}$; magnesium acetate or calcium acetate, $5 \mathrm{mM}$; sodium acetate, $0.1 \mathrm{M}$, to maintain the ionic strength. In addition extra solutes were unavoidably added along with the enzyme. Suitable corrections were made for the extra substrates or inhibitors present (see the Results section).

\section{Measurement of radioactivity incorporation}

In each experiment $2 \mu \mathrm{Ci}$ of iodo[ $\left[1{ }^{14} \mathrm{C}\right]$ acetamide (see under 'Materials') was present. Extra unlabelled iodoacetamide was added to give the correct concentration. The protein in the samples of partially inhibited enzyme in cysteine buffer was precipitated by diluting it in an excess of $5 \%(\mathrm{w} / \mathrm{v})$ trichloroacetic acid. The suspensions were left for $\frac{1}{2} \mathrm{~h}$ at $0^{\circ} \mathrm{C}$. They were then filtered through Whatman GF/C glass-fibre filters. Identical results were obtained with Sartorius membrane filters (pore size $0.45 \mu \mathrm{m}$ ), but the filtering was a slower process. The filters were washed well with $5 \%$ trichloroacetic acid, dried for $20 \mathrm{~min}$ under an i.r. lamp and counted for radioactivity in a refrigerated liquid-scintillation counter, in $5 \mathrm{ml}$ of a solution of 2,5-diphenyloxazole ( $5 \mathrm{~g} /$ litre) in toluene. The efficiency of counting was about $70 \%$. To check that the above method did not involve any selfabsorption by the protein on the filter, some experiments were carried out where the precipitate on the GF/C filters was solubilized by adding Hyamine $(0.5 \mathrm{M})$ to each filter. The filters in the vials were incubated for $30 \mathrm{~min}$ at $60^{\circ} \mathrm{C}$ and counted for radioactivity as before but by using an externalstandard channels-ratio method to determine efficiency. The results were identical with those with the insolubilized protein samples.

\section{Determination of $K_{m}$ and $K_{i}$ values}

These were carried out by using $\mathrm{pH}$-stat assays as described above.

\section{Results}

\section{Iodoacetamide reaction}

In Fig. 1 the time-course for the reaction of the enzyme with ${ }^{14} \mathrm{C}$-labelled iodoacetamide, measured by the incorporation of the latter into acid-precipitable protein, is shown. This is compared with the rate of loss of enzyme activity during the reaction. In the presence of saturating concentrations of the MgADP$\mathrm{NO}_{3}$-creatine complex the rate of reaction is much lower, but as with the unbound enzyme about one equivalent of iodoacetamide reacts per active site with corresponding loss of activity. A logarithmic plot of the data in Fig. 1 shows that with the excess of iodoacetamide used the reaction is pseudo-first-order as expected, except in the later stages of the curve with the creatine- $\mathrm{NO}_{3}-\mathrm{MgADP}$ complex, where the inhibition is rather less than expected.

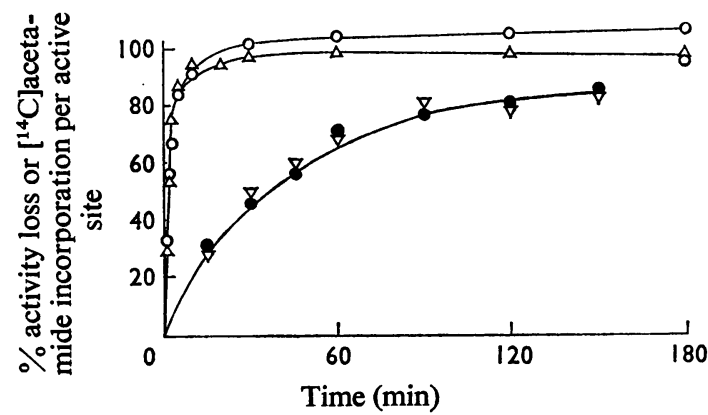

Fig. 1. Rate of reaction of the enzyme with iodoacetamide measured by $\left[{ }^{14} \mathrm{C}\right.$ ]acetamide incorporation and by loss of enzymic activity, at $25^{\circ} \mathrm{C}, \mathrm{pH} 9.0$

The solutions contained creatine kinase $(99 \mu \mathrm{g} / \mathrm{ml})$ and iodoacetamide $(0.55 \mathrm{mM})$ and Bicine $(20 \mathrm{mM})$ buffer adjusted to $\mathrm{pH} 9.0$ with $\mathrm{NaOH}$. $\mathrm{O},\left[{ }^{14} \mathrm{C}\right]$ Acetamide incorporation into protein, and $\Delta$, activity loss in the absence of substrates during the inhibition reaction. Q, $\left[{ }^{14} \mathrm{C}\right]$ Acetamide incorporation into the protein and $\nabla$, activity loss in the presence of substrates and $\mathrm{NO}_{3}{ }^{-}$to form the dead-end complex. In the latter experiments creatine $(40 \mathrm{~mm})$, magnesium acetate $(10 \mathrm{mM})$, ADP $(1 \mathrm{mM})$ and $\mathrm{NaNO}_{3}(0.1 \mathrm{M})$ were added. The second-order rate constants are: 830 litre $\cdot \mathrm{mol}^{-1} \cdot \mathrm{min}^{-1}$ in the absence of substrates and $26 \mathrm{litre} \cdot \mathrm{mol}^{-1} \cdot \mathrm{min}^{-1}$ in the presence of the dead-end complex and $\mathrm{NO}_{3}{ }^{-}$.

\section{Protection by non-working substrates and substrate complexes}

These are presented in Table 1; some further combinations of substrates and metal ions at $25^{\circ} \mathrm{C}$ are described by Milner-White \& Watts (1971).

\section{Protection by the substrate equilibrium mixture}

The effectiveness of various concentrations of an equilibrium mixture of substrates in protecting against iodoacetamide inhibition of creatine kinase is shown in Fig. 2. Each component was purified (see the Materials and Methods section) to remove any small anions that might encourage protection by the dead-end complex against iodoacetamide inhibition. The concentrations of the substrates added were adjusted so that at equilibrium each of the four substrates was expected to be fairly near to saturating the enzyme. At the abscissa in Fig. 2 the variation in concentration of only one of the four substrates is depicted. The ratios of the four substrates in the equilibrium mixture must, of course, remain constant as they are diluted. The total metal-ion concentration was the same $(10 \mathrm{~mm})$ in all the mixtures. The progress of the inhibition reaction was monitored by the loss of enzyme activity measured after dilution in a cysteine solution as described in the Materials and Methods section. 
Table 1. Protection by substrates and substrate complexes against iodoacetamide inhibition at $25^{\circ} \mathrm{C}$ and $0^{\circ} \mathrm{C}$

Protection is measured by the percentage decrease in the rate constant for activity loss in the presence of the substrate or substrate complexes. A negative value indicates rate enhancement of the inhibition reaction. The iodoacetamide concentration was $1 \mathrm{~mm}$ and $0.1 \mathrm{mM}$ at $0^{\circ}$ and $25^{\circ} \mathrm{C}$ respectively. The enzyme concentration was $990 \mu \mathrm{g} / \mathrm{ml}$ and $99 \mu \mathrm{g} / \mathrm{ml}$ at $0^{\circ} \mathrm{C}$ and $25^{\circ} \mathrm{C}$ respectively. The buffer was Bicine $(20 \mathrm{~mm})$ adjusted to pH9.0 with $\mathrm{NaOH}$. Substrate concentrations used were: creatine, $40 \mathrm{~mm}$; magnesium acetate, $10 \mathrm{~mm}$; ADP, $1 \mathrm{~mm}$; ATP, $4 \mathrm{mM}$; calcium acetate, $10 \mathrm{~mm}$; creatine phosphate, $10 \mathrm{~mm}$; $\mathrm{NaNO}_{3}, 0.1 \mathrm{M} ; \mathrm{NaCl}, 0.1 \mathrm{M}$; sodium acetate, $0.1 \mathrm{M}$.

\begin{tabular}{|c|c|c|}
\hline & $\begin{array}{r}\text { Pe } \\
\text { decre } \\
\text { c }\end{array}$ & $\begin{array}{l}\text { tage } \\
\text { in rate } \\
\text { ant }\end{array}$ \\
\hline & $0^{\circ} \mathrm{C}$ & $25^{\circ} \mathrm{C}$ \\
\hline Creatine & -10 & -4 \\
\hline Creatine phosphate & -7 & -10 \\
\hline MgADP & -8 & -20 \\
\hline MgATP & -17 & -31 \\
\hline MgADP + creatine & 49 & 5 \\
\hline ADP & -8 & -10 \\
\hline ADP + creatine & 51 & 31 \\
\hline CaADP & -48 & -36 \\
\hline $\mathrm{CaADP}+$ creatine & 35 & 10 \\
\hline $\mathrm{MgADP}+$ creatine $+\mathrm{NaNO}_{3}$ & 96 & 98 \\
\hline $\mathrm{CaADP}+$ creatine + $\mathrm{NaNO}_{3}$ & 95 & 99 \\
\hline $\mathrm{MgADP}+$ creatine $+\mathrm{NaCl}$ & 93 & 81 \\
\hline MgADP + creatine+sodium acetate & 48 & 3 \\
\hline
\end{tabular}

\section{Protection of 'forward-working' substrates}

In these experiments the enzyme at low concentration was incubated for a short period with a high concentration of iodoacetamide. When different time-intervals from 20 s up to 2 min were used, the reaction under these conditions was found as expected to be still a simple pseudo-first-order reaction with a second-order rate constant of 900 litre $\cdot \mathrm{mol}^{-1}$. In Figs. 3-6 the effects of various concentrations of forward substrates on the degree of iodoacetamide inhibition after $1 \mathrm{~min}$ are illustrated. The conditions are chosen so that the enzyme is catalysing its reaction throughout the period of inhibition; this is completed before the build-up of significant amounts of products (see the next section). The effect of the 'working' substrates is to decrease the rate constant for the inhibition reaction; thus an apparent binding constant for each of the substrates may be calculated from the decrease, $\Delta k^{\prime}$, at various substrate concentrations. The theory for this is given by Milner-White \& Watts (1971). The reciprocal plot used, analogous to a Lineweaver-Burk plot, is shown in Fig. 7, where $1 / \Delta k^{\prime}$ is plotted against $1 / s$. The value of $\Delta k^{\prime}$ when $s$, the substrate concentration, is infinite gives the

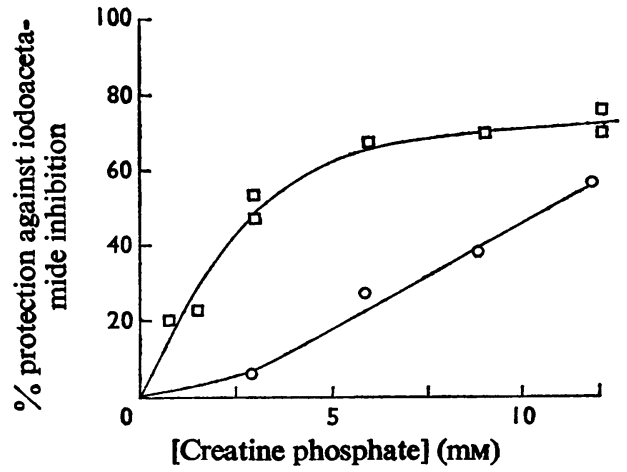

Fig. 2. Protection against iodoacetamide inhibition of creatine kinase by various concentrations of an equilibrium mixture of substrates at $\mathrm{pH} 9.0,25^{\circ} \mathrm{C}$

Activating cations were $\mathrm{Ca}^{2+}(\square)$ or $\mathrm{Mg}^{2+}(0)$. Both were acetate salts at a total concentration of $10 \mathrm{~mm}$. The protection is measured by the decrease in rate constants for inhibition of enzyme activity. The enzyme concentration was $99 \mu \mathrm{g} / \mathrm{ml}$ and the iodoacetamide concentration was $0.11 \mathrm{~mm}$. The substrates were left for $10 \mathrm{~min}$ with the enzyme before addition of the inhibitor, to allow them to come to equilibrium. The equilibrium concentration of substrates for the point on the right-hand side of the graph are: MgADP, $1.76 \mathrm{~mm}$; creatine phosphate, $11.8 \mathrm{~mm}$; MgATP, $2.24 \mathrm{~mm}$; creatine, $38.2 \mathrm{~mm}$. The corresponding values for $\mathrm{Ca}^{2+}$-activated substrates are: CaADP, $2.09 \mathrm{~mm}$; creatine phosphate, $12.1 \mathrm{mM}$; CaATP, $1.91 \mathrm{~mm}$; creatine, $39.1 \mathrm{~mm}$. The substrates remain in the same ratio to one another as they are diluted, because the amounts of substrates added initially were all decreased by the same factor.

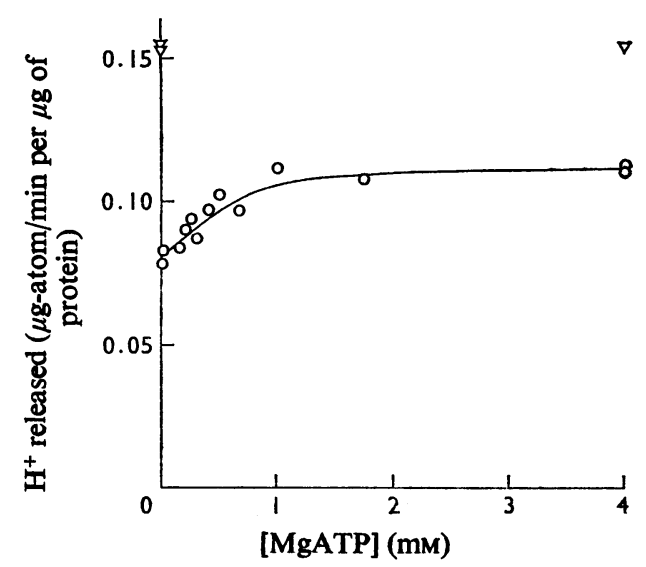

Fig. 3. Protection by the $\mathrm{Mg}^{2+}$-activated 'forward-working' substrates against iodoacetamide inhibition at $30^{\circ} \mathrm{C}, \mathrm{pH} 9.0$

The MgATP concentration was varied while the creatine concentration was kept constant at $40 \mathrm{~mm}$. The inhibition reaction tubes $(O)$ contained: creatine kinase, $2 \mu \mathrm{g} / \mathrm{ml}$; iodoacetamide, $0.8 \mathrm{~mm}$; Bicine, $10 \mathrm{~mm}$, adjusted to $\mathrm{pH} 9.0$ with $\mathrm{NaOH}$; sodium acetate, $0.1 \mathrm{M}$; free $\mathrm{Mg}^{2+}, 1 \mathrm{mM}$. Controls $(\nabla)$ were without the inhibitor. Other conditions are described in the Materials and Methods section. 


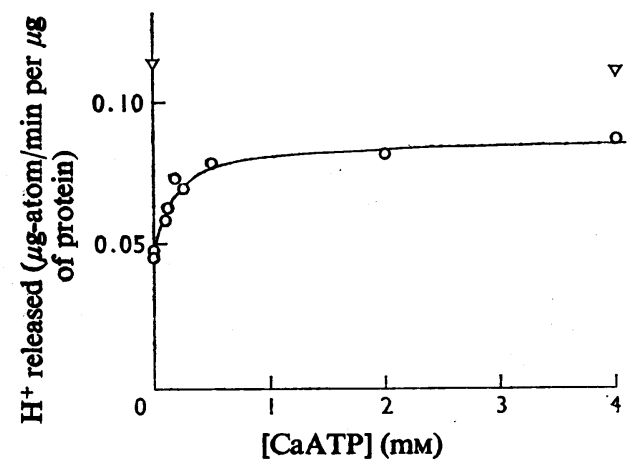

Fig. 4. Protection by the $\mathrm{Ca}^{2+}$-activated 'forward-working' substrates against iodoacetamide inhibition at $30^{\circ} \mathrm{C}$

The CaATP concentration was varied while the creatine concentration was kept constant at $40 \mathrm{~mm}$. The inhibition reaction tubes $(O)$ contained: creatine kinase, $2.99 \mu \mathrm{g} / \mathrm{ml}$; iodoacetamide, $0.8 \mathrm{~mm}$; Bicine, $10 \mathrm{~mm}$, adjusted to pH9.0 with $\mathrm{NaOH}$; sodium acetate, $0.1 \mathrm{M}$; free $\mathrm{Ca}^{2+}$, $1 \mathrm{~mm}$. Controls $(\nabla)$ were without the inhibitor. Other conditions are described in the Materials and Methods section.

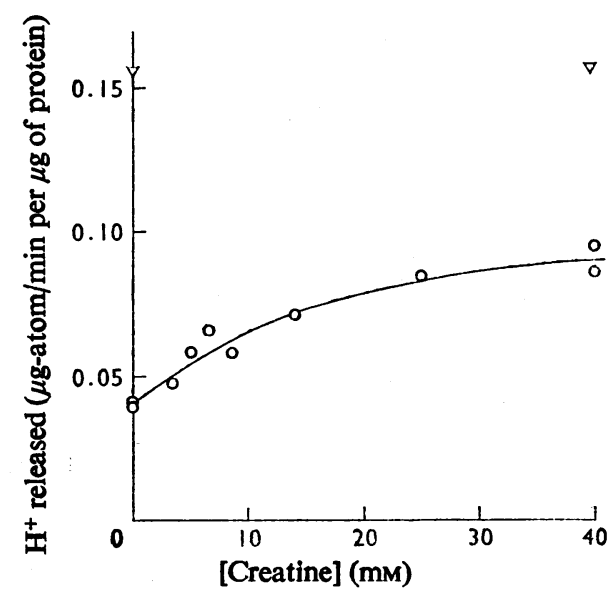

Fig. 5. Protection by the $\mathbf{M g}^{2+}$-activated 'forward-working' substrates against iodoacetamide inhibition at $30^{\circ} \mathrm{C}$

The creatine concentration was varied while the MgATP concentration was kept constant at $4 \mathrm{~mm}$; $O$, with the inhibitor; $\nabla$, without inhibitor. Conditions were as in the legend to Fig. 3.

amount of protection at saturating concentrations of the variable substrate. The corrected values are given in Table 2.

Corrections to allow for non-saturating substrate concentrations

The value of $\Delta k^{\prime}$ at infinite concentration of the variable substrate must be corrected to allow for

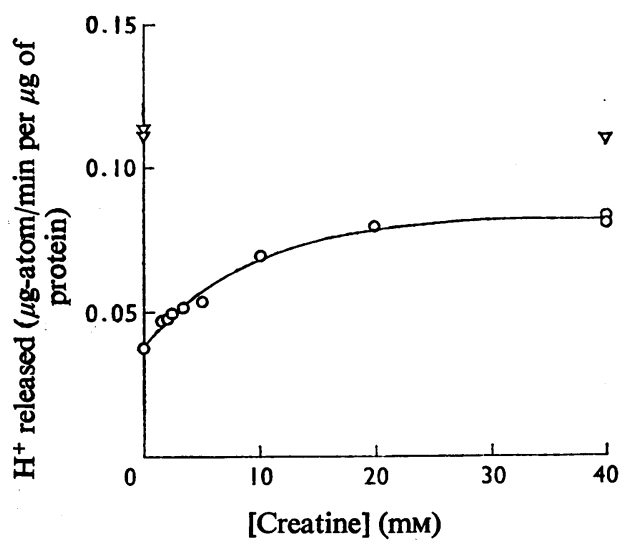

Fig. 6. Protection by the $\mathrm{Ca}^{2+}$-activated 'forward-working' substrates against iodoacetamide inhibition at $30^{\circ} \mathrm{C}$

The creatine concentration was varied while the CaATP concentration was kept constant at $4 \mathrm{mM}$; $O$, with the inhibitor; $\nabla$, without the inhibitor. Conditions were as in the legend to Fig. 4.

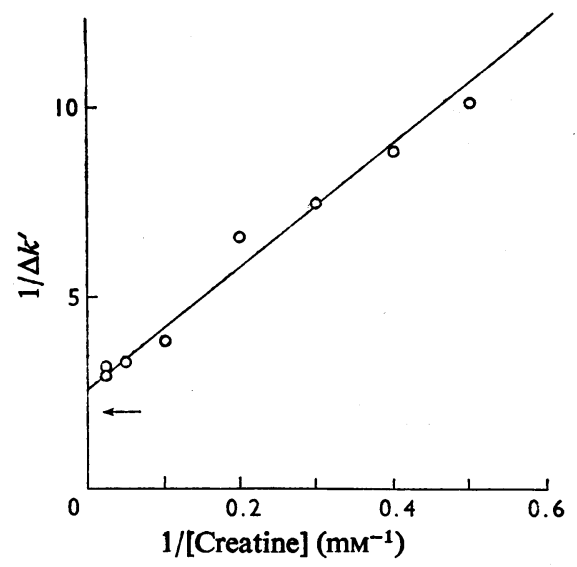

Fig. 7. Protection by the 'forward-working' substrates against iodoacetamide inhibition

Reciprocal plot of the data of Fig. 6 after making corrections (see the results section). $\Delta k^{\prime}$ is a measure of protection, being the decrease in rate constant due to the presence of two substrates, compared with that with only one. The arrow indicates the value of $1 / \Delta k^{\prime}$ that would be expected if the protection were complete.

complete saturation by the other non-varied substrate. The value is multiplied by $\left(s+K_{\mathrm{m}}\right) / s$, where $s$ and $K_{\mathrm{m}}$ refer to the non-varied substrate. This has been done by using both sets of $K_{\mathrm{m}}$ values obtained in these studies (see Table 2). However, from the studies of Morrison \& James (1965) it is known that the

Vol. 157 
Table 2. Summary of results of protection studies by 'forward-working' substrates against iodoacetamide inhibition of creatine kinase

The $K_{\mathrm{m}}$ values from protection studies were calculated from the results shown in Figs. 3-6 by using reciprocal plots like that in Fig. 7. The value for the percentage protection (expressed relative to the inhibition rate in the absence of substrates) of the reactive thiol group against iodoacetamide inhibition when the substrates are saturating was also calculated from the reciprocal plot. Corrections have been made to allow for the fact that the non-varied substrate is not saturating (see the Results section), by using either the $K_{\mathrm{m}}$ value from initial-velocity studies (column $a$ ) or the $K_{\mathrm{m}}$ value from these protection studies (column $b$ ). The $K_{\mathrm{m}}$ values from initial-velocity studies were determined by $\mathrm{pH}$-stat assays of the enzyme as described by Milner-White \& Watts (1971). They were performed under the same conditions as the protection experiments $\left(30^{\circ} \mathrm{C}\right.$; pH 9.0; sodium acetate, $0.1 \mathrm{M}$; free magnesium or calcium acetate, $1 \mathrm{mM}$ ), except that they contained cysteine ( $1 \mathrm{mM})$, but the Bicine $(10 \mathrm{~mm})$ used as buffer in the protection experiments was absent. All the $K_{\mathrm{m}}$ values reported are those at a fixed concentration of the second substrate (ATP, $4 \mathrm{~mm}$; or creatine, $40 \mathrm{~mm}$ ).

\begin{tabular}{|c|c|c|c|c|c|}
\hline \multirow{2}{*}{$\begin{array}{l}\text { Substrate } \\
\text { varied }\end{array}$} & \multirow{2}{*}{$\begin{array}{l}\text { Bivalent } \\
\text { cation }\end{array}$} & \multirow{2}{*}{$\begin{array}{l}K_{\mathrm{m}} \text { from } \\
\text { protection } \\
\text { studies } \\
(\mathrm{mM})\end{array}$} & \multirow{2}{*}{$\begin{array}{l}K_{\mathrm{m}} \text { from } \\
\text { initial-velocity } \\
\text { studies } \\
(\mathrm{mM})\end{array}$} & \multicolumn{2}{|c|}{$\begin{array}{l}\text { of reactive thiol at } \\
\text { saturating concentration } \\
\text { of substrates }\end{array}$} \\
\hline & & & & (a) & (b) \\
\hline $\begin{array}{l}\text { ATP } \\
\text { Creatine } \\
\text { ATP } \\
\text { Creatine }\end{array}$ & $\begin{array}{l}\mathrm{Mg}^{2+} \\
\mathrm{Mg}^{2+} \\
\mathrm{Ca}^{2+} \\
\mathrm{Ca}^{2+}\end{array}$ & $\begin{array}{l}0.37 \\
9.7 \\
0.095 \\
6.1\end{array}$ & $\begin{array}{l}0.5 \\
7.5 \\
0.29 \\
4.95\end{array}$ & $\begin{array}{l}75 \\
81 \\
80 \\
85\end{array}$ & $\begin{array}{l}78 \\
77 \\
82 \\
81\end{array}$ \\
\hline
\end{tabular}

binding of one substrate enhances the binding of the other; thus the $K_{\mathrm{m}}$ value to be used above should ideally be that at saturating concentrations of the other substrate, which can only be measured by extensive kinetic studies. Instead we have allowed for this by multiplying the difference between the corrected and uncorrected values of $\Delta k^{\prime}$ found above by $s /\left(s+K_{\mathrm{m}}\right)$, where $s$ and $K_{\mathrm{m}}$ refer to concentrations of the non-varied substrate (or the variable substrate in the protection experiments) used for determining the $K_{\mathrm{m}}$ value used in the initial corrections. The corrected difference is then added to $\Delta k^{\prime}$ to give the recorrected value of $\Delta k^{\prime}$.

\section{Further corrections for the protection experiments with working substrates}

There are two types of correction to be made: (1) effects on the assay directly; (2) effects of products on the rate of inhibition by iodoacetamide; (3) effects of single substrates on the rate of inhibition.

(1) Substrate and product introduced into the assay mixture with the enzyme must alter the apparent activity of the enzyme. Correction was made for the varied substrate according to eqn. (1):

$$
\frac{v_{\text {corr. }}}{v_{\text {obs. }}}=\left(\frac{K_{\mathrm{m}}+s}{K_{\mathrm{m}}+s_{\text {std. }}}\right) \frac{s_{\text {std. }}}{s}
$$

where $v_{\text {corr. }}$ is corrected initial velocity, $v_{\text {obs. }}$ is uncorrected initial velocity, $s$ is substrate concentration and $s_{\text {std. }}$ is standard substrate concentration.

Eqn. (1) is derived from the Michaelis-Menten equation. Some products, the amounts of which may be calculated, are also added with the enzyme. Correction was made according to eqn. (2) derived from the equation for competitive inhibition:

$$
\frac{v_{\text {corr. }}}{v_{\text {obs. }}}=1+\frac{K_{\mathrm{m}} i}{K_{1}\left(K_{\mathrm{m}}+s\right)}
$$

where $i$ is product inhibitor concentration.

(2) In the inhibition reaction most of the enzyme molecules are bound to the non-varied substrate, which is present at high concentration. The effect that is measured is the decrease in inhibition rate due to the binding of the second substrate. The enzyme catalyses the reaction between the substrates and liberates products which alter the inhibition rates being measured. To allow for this, average values for the decrease in concentration of enzyme-substrate complexes were worked out by using equations similar to those above. The amount of protection with product complexes is known and was calculated as a percentage of that for the enzyme bound to the non-varied substrate.

The corrected value of $\Delta k^{\prime}$ is given by eqn. (3), which is combined with both eqn. (1) and eqn. (2).

$$
\begin{aligned}
\Delta k_{\text {corr. }}^{\prime} & =\frac{v_{\text {corr. }}}{v_{\text {obs. }}} \Delta k_{\text {obs. }}^{\prime}- \\
& \frac{(\% \text { protection }) k v_{\text {corr. }} K_{\mathrm{m}}^{\mathrm{A}} i K_{\mathrm{m}}^{\mathrm{B}}}{100 V K_{\mathrm{i}} s_{\mathrm{A}}\left(K_{\mathrm{m}}^{\mathrm{B}}+s_{\mathrm{B}}\right)}
\end{aligned}
$$

where $\Delta \boldsymbol{k}_{\text {corr. }}^{\prime}$ is corrected decrease in rate constant, $\Delta k^{\prime}{ }_{\text {obs. }}$ is observed decrease in rate constant, $k$ is the constant in the presence of the non-varied substrate alone, $i$ is the average product inhibitor concentration 
and $V$ is the maximum velocity at a constant concentration of substrate $B$. A refers to the substrate with which the inhibitor competes and $B$ refers to the other substrate.

These corrections (eqns. 1-3) together correspond to alterations of not more than $10 \%$ in the specific activities plotted in Figs. 3-6 for experiments involving low ATP concentrations (the most unfavourable case) and of not more than $4 \%$ at higher ATP concentrations. The results in Figs. 3-6 are uncorrected.

(3) In the presence of a fixed concentration of a single substrate there is an equilibrium between the bound and unbound forms of the enzyme. This is unaltered as various concentrations of the other substrate are added. Although we are studying the formation of the two-substrate complex the varied substrate will also bind by itself to the enzyme to a limited extent. No attempt has been made to estimate this precisely because it was found by Morrison \& James (1965) that substrates bind less strongly individually than together with the other substrate.

Data used for these corrections are as follows. The specificactivity of the enzymeat $30^{\circ} \mathrm{C}$ is $0.150 \mu \mathrm{mol}$ of product $/ \mathrm{min}$ per $\mu \mathrm{g}$ of protein $(\mathrm{MgATP}, 4 \mathrm{~mm}$; creatine, $40 \mathrm{~mm})$, the $K_{1}$ for ADP in the presence of creatine ( $40 \mathrm{mM})$ is $0.36 \mathrm{mM}$ and the $K_{\mathrm{m}}$ for MgATP in the presence of creatine $(40 \mathrm{~mm})$ is $0.5 \mathrm{~mm}$; both these values were measured at $30^{\circ} \mathrm{C}$, at $\mathrm{pH} 9$ in $0.1 \mathrm{M}$ sodium acetate and at a free $\mathbf{M g}^{2+}$ concentration of $1 \mathrm{mM}$. Since the ADP binds more strongly to the enzyme than does creatine phosphate, for which the $K_{1}$ is $46 \mathrm{mM}$ in the presence of MgATP $(4 \mathrm{mM})$, and the $K_{\mathrm{m}}$ is $3.3 \mathrm{~mm}$ in the presence of $\operatorname{MgADP}(0.5 \mathrm{~mm})$, the inhibition by creatine phosphate can be neglected. With $\mathrm{Ca}^{2+}$ in place of $\mathrm{Mg}^{2+}$ salts, the specific activity of the enzyme is $0.110 \mu \mathrm{mol} / \mathrm{min}$ per $\mu \mathrm{g}$ of protein. The $K_{1}$ for ADP in the presence of creatine (40 mM) is $0.59 \mathrm{~mm}$; this is rather higher than one might have expected. The $K_{\mathrm{m}}$ value for CaATP in the presence of creatine $(40 \mathrm{~mm})$ is $0.29 \mathrm{~mm}$. Some of the above data are from Milner-White \& Watts (1971); some have been determined in the present work (see the legend to Table 2).

\section{Discussion}

The results of Fig. 1 agree with those of Watts et al. (1961), who showed, using the iodide electrode, that on treating creatine kinase with iodoacetamide the rate constant for iodide production is equal to that for loss of enzyme activity; complete loss of activity corresponds to the release of $2 \mathrm{~mol}$ of iodide per mol of enzyme; creatine kinase has two subunits. Our results also show that this is true for what is probably the same, but much slower, reaction when the enzyme is bound to the creatine- $\mathrm{NO}_{3}{ }^{-}-\mathrm{MgADP}$ complex.
Fig. 1 shows that after the incorporation of $1 \mathrm{~mol}$ of acetamide per subunit of the enzyme there is no further reaction. Watts et al. (1961), however, found an appreciable secondary reaction. It seems likely that this was due to the presence of the detergent Tween 80, added to prevent coating of the electrode by protein; this might have encouraged unfolding of the protein. The reactions are pseudo-first-order, as expected with an excess of iodoacetamide, but it appears from measurements at the later stages of the reaction in the presence of the creatine- $\mathrm{NO}_{3}{ }^{-}-$ MgADP complex that a few of the thiol groups may remain buried, since there is a little less enzyme modification than expected.

A transition-state-analogue complex with $\mathrm{Ca}^{2+}$ is just as effective in protecting against iodoacetamide (Table 1) as is that with $\mathbf{M g}^{2+}$. This is noteworthy in view of the fact that the rate of the $\mathrm{Ca}^{2+}$-activated enzyme-catalysed reaction is about two-thirds of that with $\mathrm{Mg}^{2+}$. Some protection experiments at $0^{\circ} \mathrm{C}$ are included in Table 1 and it is striking that the protection by creatine plus MgADP or CaADP in the absence of nitrate, chloride or formate is substantial.

The main aim of the present work is to investigate the conformation of the 'working' enzyme. An enzyme with an equilibrium constant not far from 1 , as in this case (Watts, 1973), may be incubated with its substrates and left for a while; it forms an equilibrium mixture of the substrates which are continually working in each direction. Fig. 2 shows the protection against iodoacetamide inhibition by various concentrations of a substrate equilibrium mixture at $25^{\circ} \mathrm{C}$; the amounts of each component added were adjusted so that each of the four substrates, creatine, creatine phosphate, ADP and ATP, were present in near-saturating amounts. Since the concentrations of all four substrates were varied simultaneously it is not surprising to find that the curve for the $\mathbf{M g}^{2+}$ activated reaction has a sigmoid shape, assuming that it would have shown a plateau at a value somewhere above $60 \%$ protection if it had been possible to carry out the experiment at higher substrate concentrations. Reference to Table 1 shows that the four substrates individually enhance the iodoacetamide inhibition rather than protect; the dead-end complex creatine-MgADP protects to a very small extent; appreciable protection is only seen when a small anion is added to this complex. For this reason special precautions were taken to ensure the absence of any such ions from the substrate mixtures used, as described in the Materials and Methods section. It is clear therefore that the protection seen must be ascribed to the 'working' enzyme complexes, either creatine-MgATP or creatine phosphateMgADP, and probably both, since the maximum protection seen is about $75 \%$. However, such an experiment can give no more precise information than this, since there is no easy way of quantifying 
the contribution of the different substrates and their complexes present.

The next approach therefore was to study the degree of protection of the enzyme against iodoacetamide while it was reacting in one direction only, before the formation of a significant amount of products. For this purpose a low enzyme concentration and $a$ high inhibitor concentration reacting for a short time-interval were used. Under these conditions approximately initial-velocity conditions can be obtained. The iodoacetamide reaction was measured, as before, by diluting in a cysteine solution for a short period of time and then assaying for enzyme activity. The conditions of this experiment are different from those used previously for protection studies because we wished to use the same conditions as for our other kinetic data. In this study the 'forward' substrates, creatine and ATP, were used, but it should be possible to extend the technique for the back reaction.

The information that we wish to obtain is the amount of protection against iodoacetamide inhibition with an enzyme that is completely saturated with both creatine and ATP. To determine this, the concentration of one of the substrates was varied while that of the other was kept at a high constant value (Figs. 3 and 5 for $\mathbf{M g}^{2+}$ substrates and Figs. 4 and 6 for $\mathrm{Ca}^{2+}$ substrates). The effect of both substrates bound to the enzyme is to lower the rate constant for the inhibition reaction. Thus $1 / s$ has been plotted against $1 / \Delta k^{\prime}$ (analogous to a Lineweaver-Burk plot), where $\Delta \boldsymbol{k}^{\prime}$ is the decrease in the rate constant for iodoacetamide inhibition. An example is shown in Fig. 7. From this graph the value of $\Delta k^{\prime}$ when $s$ is infinite gives the amount of protection at saturating concentrations of the variable substrate. This value is corrected by using the $K_{\mathrm{m}}$ value for the non-varied substrate to give the proportion of the enzyme saturated by both substrates (see the Results section). The value is expressed as a percentage of the value that it would have, if the protection were complete. Such measures of protection (Table 2) ought to be the same whether obtained from varying either creatine or ATP.

Another parameter that is obtained from these experiments is the apparent binding constant or ' $K_{\mathrm{m}}$ ' value. This would be expected to be equal to the $K_{\mathrm{m}}$ value obtained in the usual way, from initial-velocity kinetics. These are also given in Table 2. The two pairs of values for creatine and the pair for MgATP are quite similar, but those for CaATP are rather different. It should be pointed out that the latter result is not consistent with the simple rapid-equilibrium mechanism proposed by Morrison \& James (1965) and Morrison \& White (1967) for the binding of the substrates using $\mathrm{Ca}^{2+}$ as well as $\mathbf{M g}^{2+}$ ions.

The summary in Table 2 shows that with $\mathbf{M g}^{2+}$ the protection by saturating substrates is $75-81 \%$; the average value is $78 \%$. With $\mathrm{Ca}^{2+}$ the corresponding protection values range from 80 to $85 \%$; the average value is $82 \%$. Although it appears that with $\mathrm{Ca}^{2+}$ there may be a little more protection than with $\mathrm{Mg}^{2+}$, it is not possible to conclude whether or not there is a real difference.

Creatine kinase would be expected to catalyse the conversion of one Michaelis complex, enzymecreatine-MgATP, into the other, enzyme-creatine phosphate-MgADP, via an intermediate where the phosphorous atom of the phosphoryl group transferred is in a penta-co-ordinate state; it would be co-ordinated to both a nitrogen atom of creatine and a terminal oxygen atom of ADP. For the purposes of this paper the crucial question is whether the intermediate is sufficiently stable to form a significant proportion of the reaction pathway. This is not possible to tell from initial-velocity kinetic studies, where a simpler scheme has to be assumed in which the interconversion of Michaelis complexes is regarded as a single rate-limiting step (Morrison \& James, 1965). If the intermediate is only found transiently as a true or nearly true transition state, the protection observed must be that of the Michaelis complex. We must infer that the thiol group in this complex is in an environment so that it is only $15-25 \%$ as reactive as usual.

The other alternative is that the intermediate is stable enough to form a significant part of the pathway. The phosphorus atom is known to form fairly stable quinquivalent chemical compounds (e.g. $\mathbf{P F}_{5}$ ) (Bencovic \& Schray, 1973; Kirby \& Warren, 1967). An $\mathrm{S}_{\mathrm{N}}$ 2-type mechanism would involve such a quinquivalent atom as intermediate, whereas with an $\mathrm{S}_{\mathrm{N}}$ 2-type mechanism a $\mathrm{PO}_{3}{ }^{-}$or metaphosphate ion (analogous to $\mathrm{NO}_{3}{ }^{-}$) would be found, but the phosphorus atom would still be in a pentaco-ordinate environment. The intermediate species may be written creatine- $\mathrm{PO}_{3}-\mathrm{MgADP}$ (with an $\mathrm{S}_{\mathrm{N}}$ 2-type mechanism the phosphoryl group becomes a monoanion, but in an $S_{N}$ 2-type mechanism it retains the two negative charges throughout). With either of these mechanisms or a combination of them, some stabilization of the intermediate might be expected. We know that the protection against iodoacetamide inhibition with the transition-stateanalogue complex creatine- $\mathrm{NO}_{3}{ }^{-}-\mathrm{MgADP}$ is $\mathbf{9 8}^{-}$ $100 \%$. So it seems reasonable to predict that the percentage protection represents the proportion of enzyme molecules that have a conformation complementary to the transition-state-analogue complex. Thus the $75-85 \%$ protection may give the percentage of enzyme molecules present as a creatine- $\mathbf{P O}_{3}$ MgADP intermediate when saturated with creatine and ATP; the remaining $15-25 \%$ of unprotected enzyme would then indicate the amount of enzyme present as the Michaelis complex. These two possibilities cannot be easily resolved at present. 


\section{References}

Bencovic, S. J. \& Schray, K. J. (1973) Enzymes 8, 201-238 James, T. L. \& Cohn, M. (1974) J. Biol. Chem. 249, 2599-2604

Kirby, A. J. \& Warren, S. J. (1967) The Organic Chemistry of Phosphorus, p. 8, Elsevier, Amsterdam

Milner-White, E. J. \& Watts, D. C. (1970) Biochem. J. 118, 23P

Milner-White, E. J. \& Watts, D. C. (1971) Biochem. J. 122, 727-740

Morrison, J. F. \& James, E. (1965) Biochem. J. 97, 3752
Morrison, J. F. \& White, A. (1967) Eur. J. Biochem. 3, 145-152

O'Sullivan, W. J., Diefenbach, H. \& Cohn, M. (1966) Biochemistry 5, 2666-2673

Reed, G. H. \& Cohn, M. (1972) J. Biol. Chem. 247, 3073-3081

Reed, G. H. \& McLaughlin, A. C. (1974) Ann. N.Y. Acad. Sci. 222, 118-129

Watts, D. C. (1973) Enzymes 8, 383-455

Watts, D. C. \& Rabin, B. R. (1962) Biochem. J. 85, 507-516

Watts, D. C., Rabin, B. R. \& Crook, E. M. (1961) Biochim. Biophys. Acta 48, 360-388 